\title{
Pengaruh Media Gambar Visual Terhadap Hasil Belajar Siswa Pada Mata Pelajaran Bahasa Inggris Di MI An-Nur Pekalipan Kota Cirebon.
}

\author{
Latifah*, Isnaini \\ *Dosen Jurusan PGMI FITK IAIN Syekh Nurjati Cirebon
}

\begin{abstract}
ABSTRAK
Upaya untuk meningkatkan mutu pendidikan yang berupa peningkatan hasil belajar melalui proses pembelajaran ditingkat sekolah dipengaruhi oleh kurikulum, buku pelajaran, strategi pembelajaran, metode pembelajaran, media pembelajaran, dan sistem evaluasi. Dari beberapa faktor tersebut salah satu yang dapat mempengaruhi hasil belajar siswa adalah faktor media pembelajaran, khususnya pada mata pelajaran bahasa Inggris.

Penelitian ini merupakan penelitian yang bersifat kuantitatif dengan teknik pengumpulan data melalui tes dan angket. Teknik analisis data yang digunakan penulis setelah data terkumpul yaitu: uji normalitas, uji homogenitas, uji hipotesis berupa uji linieritas, koefisien, determinan, dan regresi linier sederhana.

Berdasarkan hasil penelitian dapat disimpulkan bahwa : 1) Rata-rata nilai $N$ Gain kelas eksperimen yaitu 0,716, dengan rincian rata-rata nilai pretest 48,22 dan rata-rata nilai posttest 85,8. 2) Respon siswa terhadap Media Gambar visual pada pembelajaran Bahasa Inggris secara umum sangat positif atau baik, karena berdasarkan rekapitulasi angket terdapat 7 item angket positif dan 3 item angket negatif, dari prosentase angket positif didapat rata-rata 87,5\%, artinya skor tersebut tergolong pada kategori sangat kuat yang berada diantara $81 \%-100 \%$. Sedangkan prosentase angket negatif didapat rata-rata $86,1 \%$, jadi skor tersebut tergolong pada kategori sangat kuat yang berada diantara 81\% - 100\%. Hal ini menunjukkan bahwa siswa merespon sangat baik terhadap penerapan Media Gambar visual. 3) Dari hasil uji koefisien determinan diperoleh nilai sebesar 58,5\% (menunjukkan besarnya pengaruh) dan uji regresi diperoleh hasil $t_{\text {hitung }}(6,279)$ lebih besar dari $t_{\text {tabel }}(1,734)$ serta signifikan $0,000<0,05$ maka $\mathrm{H}_{0}$ ditolak dan $\mathrm{H}_{\mathrm{a}}$ diterima, artinya bahwa ada pengaruh Media gambar visual terhadap hasil belajar siswa pada mata pelajaran bahasa Inggris di kelas IV MIAn-Nur Kota Cirebon.
\end{abstract}

Kata Kunci : Media Gambar, Hasil Belajar Siswa, Bahasa Inggris. 


\section{A. PENDAhuluan}

Pembelajaran merupakan suatu kegiatan yang melibatkan seseorang dalam upaya memperoleh pengetahuan, keterampilan dan nilai-nilai positif dengan memanfaatkan berbagai sumber untuk mengajar. Pembelajaran dapat melibatkan dua pihak yaitu siswa sebagai pembelajar dan guru sebagai fasilitator.

Hal ini ditegaskan oleh Hakim (2007 :1) bahwa Keberhasilan suatu proses pembelajaran diawali dengan perencanaan yang sangat matang, perencanaan yang dilakukan dengan baik, maka setengah keberhasilan sudah dapat tercapai, setengahnya lagi terletak pada pelaksanaan. Namun demikian, perencanaan yang sudah baik sistematika atau terperinci, jika pelaksanaan proses pembelajaran tidak sesuai dengan perencanaan, maka mungkin sekali akan gagal. Perencanaaan dan pelaksanaan pembelajaarn belum tentu akan mencapai keberhasilan jika dilakukan sembarangan sehingga proses pembelajaran kurang menarik, membosankan, tidak merangsang siswa untuk aktif dan kreatif, sehingga tujuan pun tidak tercapai. Oleh karena itu, perencanaan yang baik dan pelaksaaan yang tepat akan menentukan keberhasilan proses pembelajaran.

Belajar pada hakikatnya adalah proses interaksi terhadap semua situasi yang ada di sekitar individu. Belajar dapat dipandang sebagai proses yang diarahkan kepada tujuan dan proses berbuat melalui berbagai pengalaman. Belajar juga merupakan proses melihat, mengamati, dan memahami sesuatu menurut Sudjana dalam Rusman (2011: 1). Dalam kegiatan pembelajaran dilakukan oleh dua orang pelaku, yaitu guru dan siswa. Perilaku guru adalah mengajar dan perilaku siswa adalah belajar.

Sejauh ini, seorang guru dalam melaksanakan kegiatan belajar mengajar $(\mathrm{KBM})$ hanya menjelaskan dan memberikan tugas yang terkadang peserta didik merasa jenuh dan tidak memahami tentang apa yang disampaikan oleh guru, meskipun guru tersebut sudah menjelaskan. Oleh karena itu, seorang guru harus mengetahui keinginan dari peserta didik dalam proses pembelajaran. Agar dalam 
pembelajaran peserta didik mampu menangkap materi yang disampaikan oleh guru dan proses belajar mengajar pun terlaksana dengan baik.

Upaya untuk meningkatkan mutu pendidikan yang berupa peningkatan hasil belajar melalui proses pembelajaran ditingkat sekolah dipengaruhi oleh kurikulum, buku pelajaran, strategi pembelajaran, metode pembelajaran, media pembelajaran, dan sistem evaluasi. Dari beberapa faktor tersebut salah satu yang dapat mempengaruhi hasil belajar siswa adalah faktor media pembelajaran, khususnya pada mata pelajaran bahasa Inggris.

Bahasa dalam kehidupan sehari-hari sangat memegang peranan penting terutama dalam pengungkapan pikiran seseorang atau merupakan sarana untuk berfikir, menalar, menghayati kehidupan. Bahasa merupakan peran sentral dalam perkembangan intelektusl, social, dan emosional siswa,dan merupaka kunci penentu keberhasilan dalam mempelajari semua bidang studi.segala macam bisnis dan hiburan. Terlebih fungsi bahasa sebagai alat komunikasi, bahasa Inggris yang sekarang ini sebagai bahasa Internasional sangat penting sekali untuk dikuasai. Bahasa Inggris juga salah satu bahasa Internasional dan ini dipergunakan diseluruh dunia. Di Indonesia, bahasa Inggris satu bahasa asing dan meupakan salah satu subyek wajib pada kurikulum. Bahasa Inggris telah diajarkan di sekolah seperti salah satu subyek utama dari Sekolah Dasar hingga Universitas. Upaya ini bertujuan untuk meningkatkan kemampuan bahasa Inggris agar mengembangkan bahasa Inggris sebagai satu bahasa detik.

Menurut Kasihani K.E. Suyanto (2001 : 43) bahasa Inggris merupakan bahasa asing pertama yang dianggap penting untuk tujuan pengaksesan informasi, penyerapan dan pengembangan ilmu pengetahuan, teknologi, seni budaya dan pembinaan hubungan dengan bangsa-bangsa lain.

Menyadari kenyataan pentingnya bahasa Inggris di masa depan, maka pembelajaran bahasa Inggris sedini mungkin harus diterapkan di sekolah-sekolah supaya siswa mendapatkan kosakata bahasa Inggris dengan jumlah banyak. Setiap siswa pada prinsipnya berhak memperoleh peluang untuk mencapai hasil belajar 
yang memuaskan. Namun, kenyataannya sehari-hari tampak jelas bahwa siswa itu memiliki perbedaan dalam hal kemampuan intelektual, kemampuan fisik, latar belakang keluarga, kebisaan dan pendekatan belajar yang terkadang sangat mencolok antara siswa satu dengan siswa lainnya.

Proses belajar mengajar tidak lepas dari peran media didalamnya, sebab pembelajaran media merupakan suatu bagian integral dari proses pendidikan di sekolah. Kedudukan media pengajaran ada dalam komponen proses belajar mengajar sebagai salah satu upaya untuk mempertinggi interaksi guru dan siswa, interaksi siswa dengan lingkungan (Oemar Hamalik, 1989 : 1).

Gambar dapat meningkatkan aktivitas siswa dalam belajar seperti yang dikemukakan oleh Sudjana dan Rivai (2008 : 70) sebagai berikut :

Gambar fotografi itu pada dasarnya membantu mendorong para siswa dan dapat membangkitkan minatnya pada pelajaran. Membantu mereka dalam mengembangkan minatnya pada pelajaran berbahasa, kegiatan seni, dan pernyataan kreatif dalam bercerita dramatisasi, bacaan, penulisan, melukis, dan menggambar serta membantu mereka menafsirkan dan mengingatingat isi materi bacaan dari buku teks.

Kemp \& Dayton (Azhar Arsyad 2011 : 21) mengemukakan bahwa manfaat media pembelajaran berdampak positif sebagai bagian integral pembelajarn di kelas atau sebagai cara utama pembelajran langsung. Salah satu manfaat media adalah Sikap positif siswa terhadap apa yang mereka pelajari dan terhadap proses belajar dapat ditingkatkan dan Pembelajarn bias lebih menarik.

Media gambar yang peneliti ambiladalah media gambar visual diam, Menurut Rudi Susilana dan Cepi Riyana (2007 : 15) media gambar diam adalah media visual yang berupa gambar yang dihasilkan melalui proses fotografi. Jenis media gambar ini adalah foto.

Berdasarkan observasi awal di MI An-Nur Kota Cirebon diperoleh data, bahwa pembelajaran Bahasa Inggris masih monoto, bahkan gurunya jarang masuk sehingga hasil belajar siswa masih rendah, hal ini terlihat ketika Ujian Tengah Semester hanya setengah dari jumlah siswa yang mampu mencapai 
KKM yang telah ditentukan. Peneliti juga melihat, minat dan ketertarikan siswa dalam mengikuti pelajaran khususnya Bahasa Inggris masih kurang, hal ini terlihat ketika ada beberapa siswa yang mengantuk, bergurau, dan tidak memperhatikan pembelajaran dengan baik. Suasana pembelajaran di kelas yang kurang menyenangkan (serius) menghambat peserta didik untuk menikmati pembelajaran karena penggunaan model, metode belum menyesuaikan dengan karakteristik siswa, bahkan penggunaan media pembelajaran kurang dimaksimalkan dengan baik, hal ini terlihat selama proses pembelajaran guru hanya menggunakan model pembelajaran ceramah dan bercerita, sedangkan siswa hanya diam dan menyimak penuturan dari guru. Keadaan ini yang membuat siswa merasa jenuh dan bosan dengan aktivitas belajar yang dilakukanya, dan menurut penuturan hampir sebagian siswa kelas IV mengatakan bahwa pelajaran Bahasa Inggris merupakan pelajaran yang sulit dan membosankan.

Oleh sebab itu, dari penjelasan diatas, penulis ingin menggunakan media yang berbeda sehingga siswa lebih tertarik dalam mempelajari bahasa Inggris. Peneliti menggunakan media gambar dimana agar siswa sangat antusias dan tertarik untuk mengikuti pelajaran, karena dengan menggunakan media gambar siswa akan merasa senang dan tidak cepat jenuh. Tujuan akhirnya peneliti ingin agar kosa kata yang dimiliki siswa lebih banyak dan hasil belajarnya meningkat, sehingga pintu gerbang ilmu bahasa Inggris terbuka bagi mereka.

Berdasarkan alasan di atas penulis tertarik mengkaji lebih dalam, "Adakah pengaruh media gambar visual terhadap hasil belajar siswa pada mata pelajaran Bahasa Inggris di MI An-Nur Pekalipan Kota Cirebon?”

\section{B. Rumusan Masalah}

\section{Identifikasi Masalah}

Dari latar belakang masalah dapat diidentifikasi permasalahan sebagai 
berikut:

a. Masih rendahnya minat siswa untuk mengikuti proses pembelajaran dalam mata pelajaran Bahasa Inggris, hal ini terlihat dalam proses pembelajaran masih terdapat siswa yang bergurau, suasana kelas yang kurang kondusif (gaduh dan ramai).

b. Pembelajaran Bahasa Inggris selama ini masih monoton dimana penggunaan metode pembelajaran kurang dimaksimalkan yaitu hanya menggunakan metode ceramah dan tanya jawab saja.

c. Mata pelajaran bahasa Inggris sulit untuk dipelajarai

d. Hasil belajar peserta didik masih dibawah KKM yaitu 65 .

\section{Pembatasan Masalah}

Agar masalah dalam penelitian ini menjadi jelas dan mempunyai arah yang pasti dan tidak menyimpang dari sasaran maka peneliti membatasi permasalahan dalam penelitian ini yaitu sebagai berikut:

a. Hasil belajar siswa pada mata pelajaran Bahasa Inggris di kelas IV MI An-Nur Kota Cirebon dengan menggunakan media Gambar visual.

b. Pokok bahasan yang diambil pada penelitian ini adalah Membaca (memahami tulisan bahasa Inggris sangat sederhana dalam konteks kelas) dan materi yang diambil adalah Animal.

c. Respon siswa terhadap penerapan media Gambar visual pada mata pelajaran Bahasa Inggris di kelas IV MI An-Nur Kota Cirebon.

d. Pengaruh media Gambar visual terhadap hasil belajar Bahasa Inggris di kelas IV MI An-Nur Kota Cirebon.

\section{Pertanyaan Penelitian}

a. Bagaimana hasil belajar siswa dengan menggunakan media gambar visual pada mata pelajaran bahasa Inggris di kelas IV MI An-Nur Kota Cirebon?

b. Bagaimana respon siswa terhadap penerapan media gambar visual pada mata pelajaran bahasa Inggris di kelas IV MI An-Nur Kota Cirebon? 
c. Bagaimana pengaruh media gambar visual terhadap hasil belajar siswa pada mata pelajaran bahasa Inggris di kelas IV MI An-Nur Kota Cirebon?

\section{Tujuan Penelitian}

1. Untuk mengetahui hasil belajar siswa dengan menggunakan media gambar visual pada mata pelajaran bahasa Inggris di kelas IV MI An-Nur Kota Cirebon.

2. Untuk mengetahui respon siswa terhadap penerapan media gambar visual pada mata pelajaran bahasa Inggris di kelas IV MI An-Nur Kota Cirebon.

3. Untuk mengetahui pengaruh media gambar visual terhadap hasil belajar siswa pada mata pelajaran bahasa Inggris di kelas IV MI An-Nur Kota Cirebon.

\section{PEMBAHASAN}

Dalam penelitian yang dilakukan di MI An-Nur Kota Cirebon, peneliti menggunakan dua kelas berbeda yaitu kelas eksperimen (IV.1) dan kelas control (IV.2). Hal ini dilakukan untuk megetahui pengaruh pemahaman konsep siswa kelas eksperimen yang pembelajarannya diberi perlakuan dengan media gambar dan kelas kontrol yang menggunakan pembelajaran konvesional (ceramah). pembandingnya merupakan data hasil awal (pretest) dan hasil akhir (posttest) setelah adanya perlakuan. peneliti melakukan pembelajaran dikelas selama $4 \mathrm{x}$ pertemuan, baik dikelas eksperimen maupaun di kelas kontrol.

\section{Respon Siswa Terhadap Penerapan Media Gambar di kelas IV.1 MI An-Nur Kota Cirebon}

Penerapan Media Gambar, di kelas eksperimen membuat siswa menjadi aktif, mandiri dalam proses pembelajaran, selain itu mereka mampu meluapkan segala potensi yang mereka miliki karena ketika proses pembelajaranya semua indera yang mereka miliki diikutsertakan secara penuh sehingga emosi mereka 
dalam berkemauan untuk belajarpun semakin baik. Hal ini ditunjukan oleh sikap siswa yang aktif, berani, mandiri dan selalu bersemangat ketika belajar.

Sikap siswa dapat diketahui melalui hasil angket yang telah peneliti sebarkan kepada siswa kelas eksperimen. Dari hasil angket yang disebar kepada 30 responden dengan 10 penyataan, Berdasarkan analisis data hasil angket hampir sebagian siswa merespon sangat baik dengan adanya Media gambar. Berdasarkan rekapitulasi angket terdapat 7 item angket positif dan 3 item angket negatif, dari prosentase angket positif tentang media gambar yang menjawab SS dan S adalah 87,5 \%, dan yang menjawab STS dan TS adalah $12,5 \%$, jadi skor yang menjawab SS dan S tersebut tergolong pada kategori sangat kuat yang berada diantara $81 \%$ - 100\%. Sedangkan prosentase angket negatif tentang media gambar yang menjawab STS dan TS adalah $86,1 \%$, dan yang menjawab SS dan S adalah13,9\%, jadi skor yang menjawab STS dan TS tersebut tergolong pada kategori sangat kuat yang berada diantara $81 \%-100 \%$. Dapat disimpulkan bahwa penerapan media gambar sangat cocok digunakan terutama dalam pembelajaran bahasa Inggris pada materi animal.

Berdasarkan uraian diatas bahwasannya hampir semua siswa merespon positif dengan adanya pembelajaran menggunakan media gambar visual. hal tersebut sesuai dengan pendapat Azhar Arsyad (2011:15) fungsi utama media pembelajaran adalah sebagai alat bantu mengajar yang turut mempengaruhi iklim, kondisi, dan lingkungan belajar yang ditata dan diciptakan oleh guru. Sedangkan menurut Hamalik (dalam Azhar Arsyad, 2011 : 15) bahwa pemakaian media pembelajaran dalam proses belajar mengajar dapat membangkitkan keinginan dan minat yang baru, membangkitkan motivasi dan rangsangan kegiatan belajar, dan bahkan membawa pengaruh-pengaruh psikologis terhadap siswa.

\section{Hasil Belajar Siswa yang Menggunakan Media Gambar di Kelas IV.1 MI An-Nur Kota Cirebon}


Hasil tes awal siswa sebelum diadakan proses pembelajaran (pretest) untuk kelas eksperimen dan kontrol dilihat tabel rekapitulasi yang sama berdasarkan uji statisik. Untuk kelas eksperimen nilai terendah 33 dan tertinggi 60 dengan rata-rata kelas 48.2222. Sedangkan untuk kelas kontrol nilai terendah 40 dan nilai tertinggi 80 dengan rata-rata 48 .

Hasil tes siswa setelah proses pembelajaran (posttest) baik kelas eksperimen dan kelas control mengalami perubahan yang hampir sama. Untuk kelas eksperimen nilai terendah 67 dan tertinggi 100 dengan rata-rata 85,8.. Sedangkan untuk kelas kontrol nilai terendah 60 dan nilai tertinggi 93 dengan rata-rata $69,1$.

Dengan adanya nilai pretest dan posttest kita bias lihat $N$-gain. $N$-gain dari kelas eksperimen nilai trendah 0,29 dan tertinggi 1,00 dengan rata-rata 0,716. Sedangkan $N$-gain untuk kelas kontrol nilai terendah 0.00 dan tertinggi 0,89 dengan rata-rata 0,38 . Sehingga dapat diketahui perubahan atau perbedaan hasil belajar siswa sebelum dan setelah pembelajaran untuk kelas eksperimen dengan media gambar dan kelas kontrol yang menggunakan pembelajaran konvesional (ceramah) perbedaannya cukup tinggi. mengetahui hal tersebut dilakukan uji hipotesis.

Pengujian hipotesis ini dilaksanakan setelah data yang akan diuji yaitu data $N$-gain terlebih dahulu dilakukan uji normalitas dan uji homogenitas. Hal ini dilakukan untuk mengetahui jenis analisis yang akan dilakukan selanjutnya. Apabila terdapat data yang berdistribusi tidak normal atau tidak homogen maka dilakukan uji non parametrik, namun apabila data tersebut berdistribusi normal dan homogen maka dilakukan uji parametrik.

Berdasarkan tabel 4.6 tentang uji normalitas dengan menggunakan SPSS V.21, diperoleh nilai sig. kelas eksperimen dengan uji Kolmogorov-Smirnov sebesar 0,200 sedangkan dengan menggunakan uji Shapiro-Wilk sebesar 0,056, sehingga bila dilihat dari kedua uji tersebut dapat dikatakan nilai sig. $\alpha \quad(0,200$ dan 0,056 ), nilai sig. $\alpha>0,05$ dengan demikian dapat disimpulkan bahwa data 
kelas eksperimen berdistribusi normal. Sedangkan nilai sig. kelas kontrol dengan uji Kolmogorov-Smirnov sebesar 0,200 sedangkan dengan menggunakan uji Shapiro-Wilk sebesar 0,28, sehingga bila dilihat dari kedua uji tersebut dapat dikatakan nilai sig. $\alpha \quad(0,200$ dan 0,056$)$, nilai sig. $\alpha>0,05$ dengan demikian dapat disimpulkan bahwa data kelas kontrol berdistribusi normal.

Kesimpulan hipotesisnya adalah $\mathrm{H}_{0}$ diterima dan $\mathrm{H}_{\mathrm{a}}$ ditolak, artinya data sampel dari populasi yang berdistribusi normal. Hasil uji homogenitas dengan menggunakan SPSS V.21, menunjukkan bahwa nilai Sig. N-gain kelas eksperimen dan kelas kontrol berada di atas 0,05. Dengan demikian, data pada kelas eksperimen dan kelas kontrol berdistribusi homogen.

Data $N$-gain kelas eksperimen dan kelas kontrol berdistribusi normal dan homogen, maka selanjutnya untuk melihat perbedaan dua rata-rata nilai kelas eksperimen dan kontrol dilakukan pengujian Independent Sample test. Berdasarkan hasil analisis SPSS V.21, pada tabel 4.8 nilai mean gain kelas eksperimen sebesar 0,7170 dengan jumlah siswa 30. Sedangkan nilai mean gain untuk kelas kontrol didapat sebesar 0,3783 dengan jumlah siswa 30. Dengan demikian nilai eksperimen lebih besar dari nilai kontrol, artinya ada perbedaan hasil belajar kelas eksperimen dan hasil belajar kelas kontrol. untuk membandingkan rta-rata dengan Independent Sample Test digunakan dasar Equal Variance Assumed lihat table 4.9 yaitu 6,669 dengan probabilitas 0,000. Oleh karena probabilitas lebih kecil dari 0,05 maka dengan demikian hasil belajar kelas yang menggunakan media gambar (eksperimen) dengan kelas kontrol terdapat perbedaan yang signifikan, hal ini dapat terjadi karena :

a. Faktor media, metode, strategi, pendekatan dalam pembelajaran yang sangat berpengaruh terhadap antusias siswa dalam belajar.

b. Guru perlu menguasai keterampilan dasar mengajar, karena ini turut berpengaruh dalam kegiatan belajar mengajar yang optimal. 
c. Pengelolaan kelas berpengaruh terhadap hasil dari penelitian, pengelolaan kelas yang baik dapat mengakibatkan kegiatan pembelajaran yang optimal. sehingga siswa dapat belajar dengan suasana pembelajaran yang kondusif.

Data $N$-gain kelas eksperimen berdistribusi normal dan homogen dan merupakan pengujian pengaruh suatu perlakuan terhadap kelompok yang menggunakan Media Gambar, maka untuk pengujian hipotesisnya menggunakan statistik parametrik (Parametric Statistic) yaitu menggunakan uji determinasi dan uji regresi sederhana.

Berdasarkan analisis data yang dilakukan peneliti terhadap hasil pretest dan posttest, hasil belajar siswa mengalami perubahan. Guru sebelum menerapkan Media Gambar, dalam proses pembelajaran pada kelas eksperimen nilai rata-rata hasil belajar siswa adalah 48,22. Sedangkan pada nilai rata-rata hasil belajar siswa setelah guru menerapkan Media Gambar, mengalami kenaikan menjadi 85,77.

Dengan hal tersebut ditunjukkan bahwa penggunaan media gambar membuat hasil belajar siswa meningkat khusuanya pada materi Animal. Hal tersebut ditunjukkan adanya teori Gambar dapat meningkatkan aktivitas siswa dalam belajar seperti yang dikemukakan oleh Sudjana dan Rivai (2008 : 70) sebagai berikut :

Gambar fotografi itu pada dasarnya membantu mendorong para siswa dan dapat membangkitkan minatnya pada pelajaran. Membantu mereka dalam mengembangkan minatnya pada pelajaran berbahasa, kegiatan seni, dan pernyataan kreatif dalam bercerita dramatisasi, bacaan, penulisan, melukis, dan menggambar serta membantu mereka menafsirkan dan mengingat-ingat isi materi bacaan dari buku teks.

\section{Pengaruh Media Gambar Terhadap Hasil Belajar Bahasa Inggris di Kelas IV MI An-Nur Kota Cirebon}


Selain itu, peneliti melakukan uji regresi sederhana untuk mengetahui ada tidaknya pengaruh media gambar terhadap hasil belajar siswa. Berdasarkan hasil uji regresi didapatkan t hitung sebesar 6,279 serta signifikan 0,000<0,05. Untuk t tabel dicari pada taraf signifikan 5\% dengan derajat kebebasan (df) n-k1 atau 30-2-1 = 27. Dengan pengujian 2 sisi (signifikansi $=0,05)$ hasil diperoleh untuk t tabel sebesar 1,70329. Karena t hitung $(6,279)$ lebih besar dari t tabel $(1,70329)$ dan nilai probabilitas $(0,000)$ lebih kecil dari 0,05 maka $\mathrm{H}_{0}$ ditolak, artinya bahwa terdapat pengaruh yang signifikan penerapan media gambar terhadap hasil belajar siswa pada mata pelajaran bahasa Inggris di kelas IV.1 MI An-Nur Kota Cirebon.

Penggunaan media gambar visual tersebut ada berpengaruh dengan hasil belajar siswa, hal tersebut dikarenakan adanya kelebihan dalam media gambar. Menurut Asnawir dan M. Basyirudin Usman (2002: 50-51) Beberapa kelebihan dan kekurangan media gambar/foto diantaranya adalah :

Media gambar/foto mempunyai beberapa kelebihan antara lain :

1) Lebih konkrit dan realistis dalam memunculkan pokok masalah, jika dibandingkan dengan bahasa verbal.

2) Dapat mengatasi ruang dan waktu.

3) Dapat mengatasi keterbatasan mata.

4) Memperjelas masalah dalam bidang apa saja, dan dapat digunakan untuk semua orang tanpa memandang umur.

Berdasarkan pemaparan tersebut, maka terbukti secara empiris dan teoritis bahwa terdapat pengaruh yang signifikan penerapan media gambar terhadap hasil belajar siswa atau dengan kata lain, penerapan model media gambar dapat diterapkan dalam pembelajaran bahasa Inggris materi Animal sebagai upaya untuk mengembangkan wawasan siswa terlebih dapat membuat hasil belajar siswa lebih maksimal.

\section{E. KESIMPULAN}


Kesimpulan yang dapat ditarik dari hasil kegiatan penelitian yang dilakukan di SDN Argasunya Kota Cirebon adalah sebagai berikut:

1. Berdasarkan respon siswa terhadap Media Gambar Visual adalah sangat baik. karena berdasarkan interprestasi dari angket positif didapat nilai 87,5\% (mendekati sangat setuju) yang artinya terletak pada daerah yang sangat kuat. Sedangkan dari angket negative didapat nilai rata-rata 86,1\% (mendekati sangat tidak setuju) yang artinya terletak pada daerah yang kuat.Hal ini menunjukkan dari kedua angket tersebut baik angket positif maupun negative menunjukkan respon yang sangat baik terhadap Media Gambar Visual.

2. Hasil belajar siswa dengan menggunakan media gambar pada mata pelajaran bahasa Inggris pokok bahasan Animal di MI An-Nur Jagasatru Kota Cirebon adalah berbeda dari sebelum mendapatkan perlakuan dan sesudah mendapat perlakuan, yaitu sebelum guru menerapkan media gambar nilai rata-rata hasil belajar siswa adalah 48.22. Sedangkan nilai rata-rata hasil belajar siswa setelah guru menerapkan media gambar adalah 85.77, yakni hasil posttest lebih tinggi daripada hasil pretest.

3. Pengaruh penerapan Media gambar terhadap hasil belajar Bahasa Inggris dapat dilihat dari uji koefisien determinasi, Pengaruh penerapan Media gambar Visual terhadap hasil belajar Bahasa Inggris yaitu sebesar 58,8\% (menunjukkan besarnya pengaruh) dan uji regresi diperoleh hasil $t_{\text {hitung }}$ sebesar 6,279 $>\mathrm{t}_{\text {tabel }}$ sebesar 1,70329 dan nilai probabilitas $(0,000)$ lebih kecil dari 0,05 maka $\mathrm{H}_{0}$ ditolak dan $\mathrm{H}_{\mathrm{a}}$ diterima, artinya bahwa terdapat pengaruh yang signifikan penerapan media gambar visual terhadap hasil belajar siswa pada mata pelajaran bahasa Inggris di kelas IV MI An-Nur Pekalipan Kota Cirebon. 


\section{DAFTAR PUSTAKA}

Arikunto, Suharsimi. (1998a). Prosedur Penelitian Suatu Pendekatan Praktek. Edisi Revisi IV. Jakarta: Rineka Cipta.

. 2010. Prosedur Penelitian Suatu Pendekatan Praktik. Jakarta : Rineka Cipta.

. 2002. Prosedur Penelitian Suatu Pendekatan Praktek.

Yogyakarta: Rineka Cipta,

Arsyad, Azhar. 2011. Media Pembelajaran. Jakarta. PT Rajagrafindo Persada.

Asnawir dan M. Basyirudin Usman. 2002. Media Pembalajaran. Jakarta : Ciputat Pers.

Daryanto. 2011. Media Pembelajaran. Bandung: PT. Sarana Tutorial Nurani Sejahtera.

Djamarah, Syaiful Bahri. 2006. Strategi Belajar Mengajar. Jakarta: Rineka Cipta.

Djamarah, Syaiful Bahri dan Aswan Zain. 2002. Strategi Belajar Mengajar. Jakarta: Rineka Cipta.

Fathurrohman, Pupuh. 2011. Strategi Belajar Mengajar Melalui Penanaman Konsep Umum dan Konsep Islam. Bandung: Refika Aditama.

Hamalik, Oemar 1989. Media Pendidikan. Bandung :PT Citra Aditya Karya.

Hamdani. 2011. Strategi Belajar Mengajar. Bandung. Pustaka Setia.

Purwanto. 2010. Evaluasi Hasil Belajar. Yogyakarta. Pustaka Pelajar.

Purwanto, Ngalim. 2008. Prinsip-Prinsip dan Teknik Evaluasi Pengajaran. Bandung: PT. Remaja Rosdakarya.

Raharja, Hendri. 2009. Suplemen Multimedia Pembelajaran Berbasis Komputer, Cirebon : Pangger.

Riduwan. 2011. Dasar-Dasar Statistika. Bandung : Alfabeta.

S. Sadiman, Arif, dkk. 2012. Media Pendidikan. Jakarta. PT Rajagrafindo Persada. 
Sudjana, Nana. 2012. Penilaian Hasil Proses Belajar Mengajar. Bandung: PT. Remaja Rosdakarya.

Sudjana, Nana dan Ahmad Rivai. 2013. Media Pengajaran. Bandung. Sinar Baru Algensindo.

Sugiyono, 2012. Metode Penelitian Pendidikan. Bandung : Alfabeta.

Syaodih, Nana. 2004. Landasan Psikologi Proses Pendidikan. Bandung. PT Remaja Rosdakarya.

Syah, Muhibin. 2004. Psikologi Belajar. Jakarta: PT. Raja Grafindo Persada.

Yamin, Martinis. 2007. Desain Pembelajaran Berbasis Tingkat Satuan Pendidikan. Jakarta: Gaung Persada Press.

Zahrotul Zannah, 2014:40 ((http://www.physics.iastate.edu/per/docs/Addedum on normalized gain.pdf (diakses tanggal 1 april 2013) dalam skipsi). 